\title{
Tellurite reductase activity of nitrate reductase is responsible for the basal resistance of Escherichia coli to tellurite
}

\author{
Cécile Avazéri, ${ }^{1}$ Raymond J. Turner, ${ }^{2}$ Jeanine Pommier, ${ }^{3}$ Joël H. Weiner, ${ }^{2}$ \\ Gérard Giordano ${ }^{3}$ and André Verméglio ${ }^{1}$
}

Author for correspondence: André Verméglio. Tel: +334422546 30. Fax: +33442254701. e-mail:vermeglio@DRA.CAD.CEA.FR

\footnotetext{
1 Laboratoire de

Bioénergétique Cellulaire, Département

d'Ecophysiologie Végétale et Microbiologie, CEA Cadarache, 13108 Saint

Paul lez Durance, France

2 MRC Group in the Molecular Biology of Membranes, Department of Biochemistry, University of Alberta, Edmonton, Alberta, Canada T6G $2 \mathrm{H} 7$

3 Laboratoire de Chimie Bactérienne, CNRS, 31 Chemin Joseph Augier, 13402 Marseille Cedex 20, France
}

\begin{abstract}
Tellurite and selenate reductase activities were identified in extracts of Escherichia coli. These activities were detected on non-denaturing polyacrylamide gels using an in situ methyl viologen activity-staining technique. The activity bands produced from membrane-protein extracts had the same $R_{F}$ values as those of nitrate reductases (NRs) A and Z. Tellurite and selenate reductase activities were absent from membranes obtained from mutants deleted in NRs A and Z. Further evidence of the tellurite and selenate reductase activities of NR was demonstrated using rocket immunoelectrophoresis analysis, where the tellurite and selenate reductase activities corresponded to the precipitation arc of NR. Additionally, hypersensitivity to potassium tellurite was observed under aerobic growth conditions in nar mutants. The tac promoter expression of NR A resulted in elevated tellurite resistance. The data obtained also imply that a minimal threshold level of NR A is required to increase resistance. Under anaerobic growth conditions additional tellurite reductase activity was identified in the soluble fraction on non-denaturing gels. Nitrate reductase mutants were not hypersensitive under anaerobic conditions, possibly due to the presence of this additional reductase activity.
\end{abstract}

Keywords: nitrate, tellurite and selenate reductase, tellurite resistance

\section{INTRODUCTION}

Tellurium and selenium oxyanions are found as trace components in natural environments as well as in higher concentrations within polluted soils and water. Tellurium compounds can be found in high concentrations near sites of waste discharge, while selenium is present, in the soluble selenate form, in alkaline soils and water. Some of the tellurium and selenium oxyanions are toxic to micro-organisms. The toxicity of potassium tellurite to micro-organisms, particularly Gram-negative bacteria, is well established, yet the mechanism is not fully understood (Summers \& Jacoby, 1977; Turner et al., 1995). Some Gram-positive organisms (Corynebacterium diphtheriae, Streptococcus faecalis and some Staphylococcus aureus strains) are naturally resistant to potassium tellurite, but little is known about the mechanisms responsible for this resistance (Summers \& Silver, 1978). Many bacteria can acquire

Abbreviation: NR, nitrate reductase. high resistance when transformed with multi-drug resistance plasmids, many of which encode tellurite resistance (Summers \& Jacoby, 1977; Walter et al., 1991; Turner et al., 1992; Hill et al., 1993; Lloyd Jones et al., 1994; Taylor et al., 1994). Resistance to tellurite is conferred by highly specific genetic determinants (Walter \& Taylor, 1992).

Historically, tellurite has been used as an indicator for the localization of reducing activity in bacteria (Barrnett \& Palade, 1957; Van Iterson \& Leene, 1964). However, the enzymes responsible for this tellurite to tellurium reduction were unknown. One possible mechanism to detoxify tellurite $\left(\mathrm{TeO}_{3}^{2-}\right)$ is to reduce it to metallic tellurium $\left(\mathrm{Te}^{0}\right)$. Indeed, bacteria grown on media containing potassium tellurite form black colonies due to intracellular deposition of tellurium (Turkey et al., 1962; Taylor et al., 1988; Lloyd Jones et al., 1994; Moore \& Kaplan, 1992). Selenium, in the form of either $\mathrm{SeO}_{3}^{2-}$ or $\mathrm{SeO}_{4}^{2-}$, is also reduced to $\mathrm{Se}^{0}$ and deposited along the cell membranes (Gerrard et al., 1974; Macy, 1994). Since tellurium and selenium are within the same 
group in the periodic table as sulfur, they possess some similarities in their chemistry. The possibility that micro-organisms involved in the sulfur cycle can also reduce selenate was investigated by Zehr \& Oremland (1987). They concluded that only trace amounts of selenate (picomolar-nanomolar) were reduced via the sulfate reduction pathway. More recently, field studies by Oremland (1994) support the idea that selenate reduction is carried out by one or more of the enzymes involved in dissimilatory nitrate reduction (denitrification).

Complete denitrification (i.e. reduction of nitrate to nitrogen) requires four different enzymes: nitrate, nitrite, nitric oxide and nitrous oxide reductases. The first step in the reduction of nitrate in Escherichia coli is performed by two dissimilatory membrane-bound nitrate reductases (NR) denoted $\mathrm{A}$ and $\mathrm{Z}$. The former, NR $\mathrm{A}$, is encoded by the narGHIJ operon, induced under anaerobic conditions when nitrate is present in the culture medium, repressed by oxygen, and controlled by the $f n r$ global anaerobic regulator (Blasco et al., 1989; Stewart, 1982; Kapraleck et al., 1982; Chippaux et al., 1981). NR A, which contains molybdenum, iron-sulfur centres (Vincent et al., 1978) and cytochrome $b$, possesses three polypeptide subunits: $\alpha$ (NarG), $\beta$ (NarH) and $\gamma$ (NarI) with approximate $M_{\mathrm{r}} 155000,60000$ and 25000 , respectively. NarJ is found in the structural operon for NR, but it is not a component of the active enzyme and its function is unclear (Sodergren \& DeMoss, 1988). NR $Z$ is encoded by the narZYWV operon and is constitutively expressed at low levels, even in aerobic conditions. The two operons coding for NR A and NR Z are similar and located at $32.5 \mathrm{~min}$ and $27 \mathrm{~min}$, respectively, on the E. coli chromosome (Blasco et al., 1990). It is thought that narZYWV and narGHIJ descended from a common ancestor by gene duplication, and so the two enzymes have great structural resemblance (Bonnefoy et al., 1987; Iobbi et al., 1987; IobbiNivol et al., 1990).

In this study, we show that NRs from E. coli also have tellurite and selenate reduction activities and are responsible for the natural resistance of E. coli to tellurite. We also identify a soluble enzyme in anaerobically grown cells which reduces tellurite.

\section{METHODS}

Bacterial strains, plasmids and media. The strains of $E$. coli used are listed in Table 1 . They were grown under anaerobic or aerobic conditions at $37^{\circ} \mathrm{C}$ in Luria-Bertani (LB) broth medium (Miller, 1992). Potassium tellurite and sodium selenate were added to final concentrations of $10 \mu \mathrm{M}$ and $100 \mu \mathrm{M}$, respectively. For the induction of NR A, potassium nitrate was added to a final concentration of $1 \mathrm{~g} \mathrm{l}^{-1}$. Plasmids were maintained by adding $50 \mu \mathrm{g}$ ampicillin $\mathrm{ml}^{-1}$. For the mutant LCB79/pVA700, IPTG was added to $0.2 \mathrm{mM}$.

Minimal inhibitory concentration (MIC). The MIC was defined as the lowest concentration of inhibitor preventing growth of E. coli strains at $37^{\circ} \mathrm{C}$ as previously described (Turner et al., 1995). Once autoclaved, LB agar was cooled to $\sim 50^{\circ} \mathrm{C}$ and $\mathrm{K}_{2} \mathrm{TeO}_{3}$ was added to each flask to an appropriate concentration from a stock solution of $10 \mathrm{mg} \mathrm{ml}^{-1}$. When used, nitrate was added to $1 \mathrm{~g} \mathrm{l}^{-1}$ and IPTG to $0 \cdot 1-0 \cdot 2 \mathrm{mM}$. Selenate, selenite and tellurate MIC assays were performed similarly using stock solutions of $100 \mathrm{mg} \mathrm{Na}_{2} \mathrm{SeO}_{4} \mathrm{ml}^{-1}, 100 \mathrm{mg}$ $\mathrm{Na}_{2} \mathrm{SeO}_{3} \mathrm{ml}^{-1}$ and $0 \cdot 1 \mathrm{mg} \mathrm{K}_{2} \mathrm{TeO}_{4} \mathrm{ml}^{-1}$. All stock solutions were filter-sterilized.

Preparation of cell extracts. All steps were done at $4{ }^{\circ} \mathrm{C}$. Cells were harvested, during the exponential phase of growth, by centrifugation at $4000 \mathrm{~g}$ for $10 \mathrm{~min}$, washed with $40 \mathrm{mM}$ Tris $/ \mathrm{HCl}(\mathrm{pH} \mathrm{7.6)}$ and then resuspended in the same buffer. Crude extracts were prepared by twice passing the cell suspension through a French pressure cell at $7 \mathrm{MPa}$. Proteases were inhibited by the addition of $1 \mathrm{mM}$ AEBSF [4-(2aminoethyl)-benzenesulfonyl fluoride]. The crude extract was then centrifuged at $18000 \mathrm{~g}$ for $25 \mathrm{~min}$ in order to sediment unbroken cells. The supernatant fraction obtained was ultracentrifuged at $200000 \mathrm{~g}$ for $90 \mathrm{~min}$ to separate membrane and soluble fractions. The pellet containing membranes was washed in $40 \mathrm{mM}$ Tris/ $\mathrm{HCl}(\mathrm{pH} 7.6)$ and then ultracentrifuged again.

Protein content was determined using the Lowry method.

Polyacrylamide gels. Electrophoresis under non-denaturing conditions was carried out as described by Iobbi-Nivol et al. (1990). A separating gel with $7 \cdot 5 \%$ acrylamide containing $0.1 \%$ Triton X-100, and a stacking gel (3\% acrylamide containing $0.1 \%$ Triton $\mathrm{X}-100)$ were prepared from a stock solution ( $30 \%$ acrylamide, $0.8 \%$ bis-acrylamide). The buffer system was $25 \mathrm{mM}$ Tris (pH 8.5), $192 \mathrm{mM}$ glycine, $0.02 \%$ Triton X-100. Gels were stained with Coomassie brilliant blue $\mathrm{R} 250$ for protein detection.

Enzyme assays. Nitrate, tellurite and selenate reductase activities were assayed spectrophotometrically with reduced benzyl viologen as the electron donor (Jones \& Garland, 1977). The reaction mixture $(3.5 \mathrm{ml})$ contained $40 \mathrm{mM}$ Tris/ $\mathrm{HCl}$ buffer ( $\mathrm{pH} \mathrm{7.6)}$ degassed and sparged with high-purity argon, and $0.6 \mathrm{mM}$ benzyl viologen reduced with enough $\mathrm{Na}_{2} \mathrm{~S}_{2} \mathrm{O}_{4}$ to give an $A_{595}$ of $\sim 1 \cdot 0$. The different substrates introduced were $\mathrm{KNO}_{3}(40 \mathrm{mM}), \mathrm{K}_{2} \mathrm{TeO}_{3}(160 \mathrm{mM})$ or $\mathrm{Na}_{2} \mathrm{SeO}_{4}(160 \mathrm{mM})$.

The enzymic activities were also visualized on non-denaturing polyacrylamide gels (Lund \& DeMoss, 1976; Iobbi et al., 1987). The gels were incubated in $40 \mathrm{mM}$ Tris/ $\mathrm{HCl}$ buffer $(\mathrm{pH}$ 7.6) containing $0.6 \mathrm{mM}$ methyl viologen reduced with $\mathrm{Na}_{2} \mathrm{~S}_{2} \mathrm{O}_{4}$. The enzyme activity was visualized by the appearance of a clear band on the gel, impregnated with reduced methyl viologen (which results in a dark-blue-stained gel), after introduction of substrates $\mathrm{KNO}_{3}(40 \mathrm{mM}), \mathrm{K}_{2} \mathrm{TeO}_{3}$ (160 mM) or $\mathrm{Na}_{2} \mathrm{SeO}_{4}(160 \mathrm{mM})$.

Rocket immunoelectrophoresis. This was performed as described by Graham et al. (1980). Agarose plates $(4 \times 4 \mathrm{~cm}$; $6 \mathrm{ml}$ ) containing $1 \%$ agarose in which $100 \mu \mathrm{l}$ antiserum was incorporated were used. The protein concentration loaded in the agarose gel was $4 \mathrm{mg} \mathrm{ml}^{-1}$ for strains MC4100, LCB 2048 and TP100, and $1 \mathrm{mg} \mathrm{ml}^{-1}$ for LCB 333/pVA70. The protein migrated overnight at $2 \mathrm{~mA}$ in a solution of $20 \mathrm{mM}$ sodium barbital (pH 8.6) and Triton X-100 (1\%).

Growth on oxyanions. The wild-type strain MC4100 was grown in a minimal salts medium with $1 \%(\mathrm{v} / \mathrm{v})$ glycerol as the non-fermentable carbon source in $9 \mathrm{ml}$ screw-top culturetubes. The oxyanions were added at subinhibitory concentrations as follows: $\mathrm{K}_{2} \mathrm{TeO}_{3}, 1$ and $4 \mu \mathrm{g} \mathrm{ml}^{-1} ; \mathrm{K}_{2} \mathrm{TeO}_{4}, 2 \mu \mathrm{g}$ $\mathrm{ml}^{-1} ; \mathrm{Na}_{2} \mathrm{SeO}_{3}, 100 \mu \mathrm{g} \mathrm{ml}^{-1}, 1$ and $10 \mathrm{mg} \mathrm{ml}^{-1}$; and $\mathrm{Na}_{2} \mathrm{SeO}_{4}$, $100 \mu \mathrm{g} \mathrm{ml}^{-1}, 1$ and $10 \mathrm{mg} \mathrm{ml}^{-1}$. HB101/pVA700 was grown in the presence of 8 and $16 \mu \mathrm{g} \mathrm{K}_{2} \mathrm{TeO}_{3} \mathrm{ml}^{-1}$. MC4100 and HB101 were also transformed with tellurite-resistance determinants tehAB (Taylor et al., 1994) and klaAklaBtelB (Turner et al., 
Table 1. Bacterial strains and plasmids

\begin{tabular}{|c|c|c|c|}
\hline $\begin{array}{l}\text { Plasmid/ } \\
\text { strain }\end{array}$ & Description/genotype & Phenotype & Reference \\
\hline pVA70 & narGHIJ regulated by $\mathrm{p}-n a r, \mathrm{Amp}^{\mathrm{r}}$ & NR A overexpressed & Guigliarelli et al. (1992) \\
\hline pVA700 & narGHIJ regulated by p-tac, $A m p^{r}$ & $\begin{array}{l}\text { NR A expressed by addition of } \\
\text { IPTG }\end{array}$ & Guigliarelli et al. (1996) \\
\hline pLCB14 & narZYWV constitutively expressed, Amp ${ }^{\mathrm{r}}$ & NR Z overexpressed & Bonnefoy et al. (1987) \\
\hline pTWT100 & tehAtehB constitutively expressed, Amp ${ }^{\mathrm{r}}$ & Tellurite resistance to $128 \mu \mathrm{g} \mathrm{ml}^{-1}$ & Taylor et al. (1994) \\
\hline pDT1558 & klaAklaBtelB constitutively expressed, Amp ${ }^{r}$ & Tellurite resistance to $256 \mu \mathrm{g} \mathrm{ml}^{-1}$ & Walter et al. (1991) \\
\hline MC4100 & $\operatorname{araD139}$ (lacIPOZYA-argF) rpsL thi & Parental strain & Casadaban (1976) \\
\hline HB101 & $\begin{array}{l}\mathrm{F}^{\prime} \text { hsdS2O }\left(\mathrm{r}_{\mathrm{B}}^{-} \mathrm{m}_{\mathrm{B}}^{-}\right) \text {leu supE44 ara14 galK2 lacY1 } \\
\text { proA2 rpsL } 20\end{array}$ & & Boyer \& Roulland-Dussoix (1969) \\
\hline LCB2048 & LCB333 $\Delta$ narZYWV & $\mathrm{NR}^{-}{ }^{-} \mathrm{NR} \mathrm{Z}^{-}$ & Blasco et al. (1992) \\
\hline LCB333 & thi-1 leu-6 thr-1 tonA21 lacY1 supE44 snar-25 & $\mathrm{NR} \mathrm{A}^{-}$ & Blasco et al. (1992) \\
\hline LCB79 & MC4100 $\phi 79($ nar-lac $)$ & $\mathrm{NR} \mathrm{A}^{-}$ & Pascal et al. (1982) \\
\hline TP100 & MC4100 $\triangle m o b A B$ & NR present but inactive & Palmer et al. (1996) \\
\hline
\end{tabular}

1994) using plasmids pTWT100 and pDT1558, respectively. In the cases of growth with tellurite-resistance determinants, $\mathrm{K}_{2} \mathrm{TeO}_{3}$ was added at concentrations of 50 and $100 \mu \mathrm{g} \mathrm{ml}^{-1}$. Control cultures were grown with $1 \mathrm{mg} \mathrm{ml}^{-1}$ and $100 \mu \mathrm{g} \mathrm{ml}^{-1}$ $\mathrm{KNO}_{3}$. The degree of growth was assessed after $48 \mathrm{~h}$ as $\mathrm{OD}_{600}$.

\section{RESULTS}

\section{Nitrate, tellurite and selenate reductase activities in E. coli membrane extracts}

The tellurite $\left(\mathrm{TeO}_{3}^{2-}\right)$, tellurate $\left(\mathrm{TeO}_{4}^{2-}\right)$, selenite $\left(\mathrm{SeO}_{3}^{2-}\right)$ and selenate $\left(\mathrm{SeO}_{4}^{2-}\right)$ reductase activities were measured spectrophotometrically at $595 \mathrm{~nm}$, by fol- lowing the oxidation of reduced benzyl viologen $\left(\mathrm{BV}^{-}\right)$ acting as electron donor. No BV - oxidation activity was observed with tellurate or selenite as electron acceptors. The tellurite and selenate reductase activities obtained for different mutants and growth conditions are compared in Table 2. For all strains studied, the tellurite or selenate reductase activities were roughly proportional to the NR activity. For example, these activities were increased in the mutants overexpressing NR A (LCB333/pVA70, LCB79/pVA700) compared to the parental strain, MC4100. Additionally, no BV oxidation activity was observed with nitrate, tellurite or selenate as electron acceptors for membranes of strain

Table 2. Nitrate, tellurite and selenate reductase specific activities in membrane fractions from wild-type and nar mutants

Cultures were grown under anaerobic $\left(-\mathrm{O}_{2}\right)$ or aerobic $\left(+\mathrm{O}_{2}\right)$ conditions in LB medium as described in Methods. Strain LCB79/pVA700 was grown in the presence of $0.2 \mathrm{mM}$ IPTG. The specific activities are expressed as $\mu \mathrm{mol}$ oxyanion reduced $(\mathrm{mg} \text { protein })^{-1} \mathrm{~min}^{-1}$. Variation of specific activities was within $\pm 10 \%$ of the mean $(n=5)$.

\begin{tabular}{|c|c|c|c|c|}
\hline \multirow[t]{2}{*}{ Strain } & \multirow{2}{*}{$\begin{array}{c}\text { Culture } \\
\text { conditions }\end{array}$} & \multicolumn{3}{|c|}{ Reductase specific activity: } \\
\hline & & Nitrate & Tellurite & Selenate \\
\hline \multirow[t]{2}{*}{ MC4100 } & $-\mathrm{O}_{2}$ (control) & 0.27 & $0 \cdot 10$ & $0 \cdot 17$ \\
\hline & $-\mathrm{O}_{2}+\mathrm{KNO}_{3}$ & $0 \cdot 68$ & $0 \cdot 26$ & $0 \cdot 25$ \\
\hline \multirow[t]{2}{*}{ LCB2048 } & $-\mathrm{O}_{2}$ (control) & $<0.002$ & $<0.002$ & $<0.002$ \\
\hline & $-\mathrm{O}_{2}+\mathrm{KNO}_{3}$ & $<0.002$ & $<0.002$ & $<0.002$ \\
\hline \multirow[t]{2}{*}{ LCB333/pVA70 } & $-\mathrm{O}_{2}$ (control) & $1 \cdot 45$ & 0.48 & $0 \cdot 30$ \\
\hline & $-\mathrm{O}_{2}+\mathrm{KNO}_{3}$ & $2 \cdot 97$ & 0.98 & $0 \cdot 58$ \\
\hline \multirow[t]{2}{*}{ LCB79/pLCB14 } & $-\mathrm{O}_{2}$ (control) & $0 \cdot 25$ & 0.06 & 0.09 \\
\hline & $-\mathrm{O}_{2}+\mathrm{KNO}_{3}$ & $0 \cdot 27$ & $0 \cdot 10$ & $0 \cdot 10$ \\
\hline \multirow[t]{2}{*}{ LCB79/pVA700 } & $+\mathrm{O}_{2}$ (control) & $2 \cdot 08$ & $0 \cdot 76$ & $0 \cdot 45$ \\
\hline & $+\mathrm{O}_{2}+\mathrm{KNO}_{3}$ & $2 \cdot 05$ & 0.72 & $0 \cdot 42$ \\
\hline \multirow[t]{2}{*}{ TP100 } & $-\mathrm{O}_{2}$ (control) & $<0.002$ & $<0.002$ & $<0.002$ \\
\hline & $-\mathrm{O}_{2}+\mathrm{KNO}_{3}$ & $<0.002$ & $<0.002$ & $<0.002$ \\
\hline
\end{tabular}


(a)

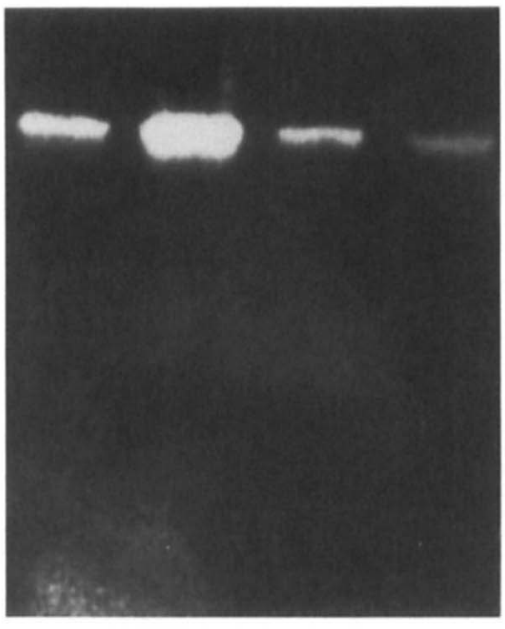

1

2

3

4 (b)

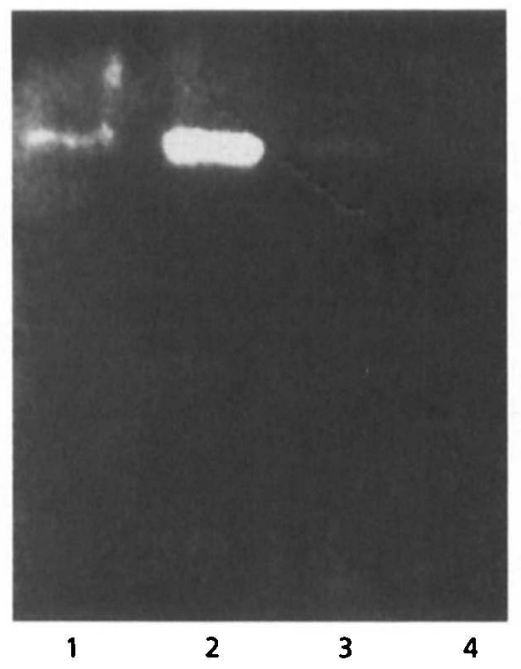

(c)

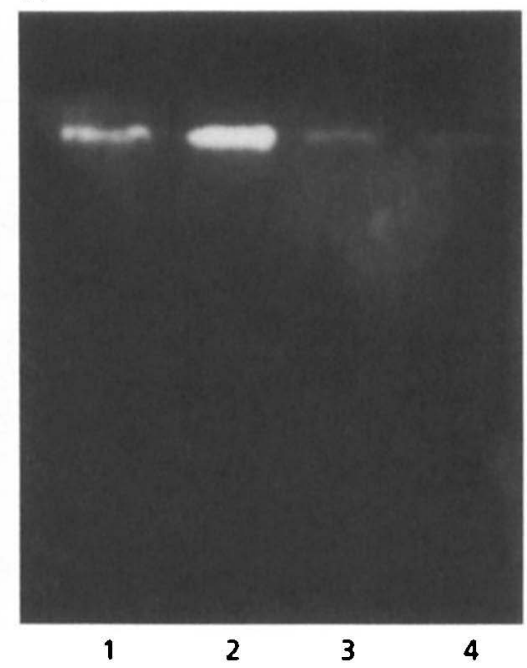

Fig. 1. Identification of nitrate (a), tellurite (b) and selenate (c) reductase activities in membrane extracts on nondenaturing polyacrylamide gels. Activities were revealed after migration on a $7.5 \%$ non-denaturing polyacrylamide gel loaded with Triton X-100-solubilized membrane extracts as described in Methods. Lanes: 1, parental strain MC4100 grown anaerobically at $37^{\circ} \mathrm{C}$ on LB medium; $2, \mathrm{MC} 4100$ grown in the presence of $1 \mathrm{~g} \mathrm{KNO}_{3} \mathrm{I}^{-1} ; 3, \mathrm{MC} 4100$ grown in the presence of $10 \mu \mathrm{M} \mathrm{K}_{2} \mathrm{TeO}_{3} ; 4, \mathrm{MC} 100$ grown in the presence of $100 \mu \mathrm{M} \mathrm{Na} \mathrm{SeO}_{4}$. In all cases $60 \mu \mathrm{g}$ protein was loaded onto the gels.

LCB2048 (deleted in NR A and NR Z) or strain TP100 (altered in the biosynthesis of the molybdenum cofactor) whatever the culture conditions. The addition of nitrate during anaerobic growth induces an increase of nitrate, tellurite and selenate reductase activities in the parental strain (MC4100) and the mutant overexpressing NR A (LCB333/pVA70). NR Z (LCB79/pLCB14) is constitutively expressed, but does not accumulate to very high levels (Iobbi et al., 1987). However, there is still significant $B V \cdot$ oxidation activity with selenate and tellurite compared to the deletion mutant (LCB2048). In plasmid pVA700, NR A synthesis is under the control of the tac promoter and is induced by addition of IPTG. Similar activities were observed under aerobic or anaerobic conditions (plus or minus nitrate). We conclude from this series of experiments that NR catalyses the tellurite and selenate reductase activities.

\section{Nitrate, tellurite and selenate reductase activities from membrane extracts in non-denaturing gels}

We monitored tellurite and selenate reductase activities using non-denaturing gels of membrane fractions of the parental strain, MC4100, grown under anaerobic conditions. The reductase activities in this case were assessed with reduced methyl viologen $\left(\mathrm{MV}^{-}\right)$as electron donor. A single clear band, due to the oxidation of the $M V^{-}$, appeared immediately after addition of tellurite or selenate, as electron acceptor, to nondenaturing gels of the membrane fraction. This is shown in Fig. $1(b, c)$ for membranes of E. coli grown under different conditions. Fig. 1 also shows that the enzymes responsible for the tellurite and selenate reductase activities migrated at an $\mathrm{R}_{F}$ of $0 \cdot 2$, identical to the $\mathrm{R}_{F}$ (a)

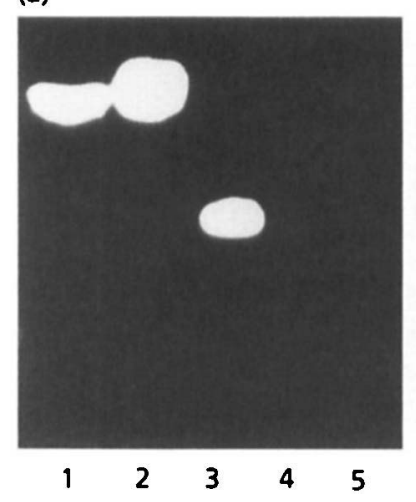

(b)

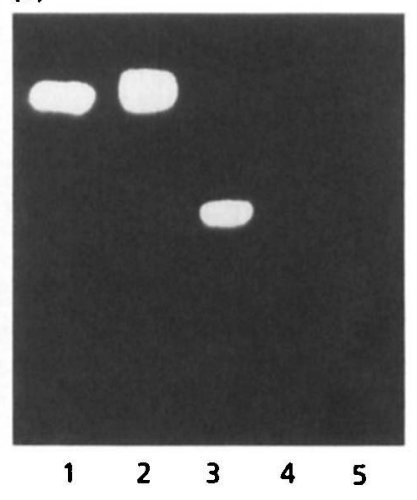

Fig. 2. Specificity of nitrate (a) and tellurite (b) activities in wild-type and nar mutants of $E$. coli. Membrane extracts were loaded onto $7.5 \%$ non-denaturing polyacrylamide gels. All the mutants were grown anaerobically in presence of $1 \mathrm{~g}$ potassium nitrate $\mathrm{I}^{-1}$. Lanes: 1 , parental strain MC4100 (100 $\mu \mathrm{g}$ protein); 2, LCB333/pVA70, mutant overexpressing NR A $(100 \mu \mathrm{g}$ protein); 3, LCB79/pLCB 14, mutant overexpressing NR Z (300 $\mu \mathrm{g}$ protein); 4, LCB2048, mutant deleted in the two membranebound NRs ( $100 \mu \mathrm{g}$ protein); 5, TP100, mutant deficient in the synthesis of the molybdenum cofactor, NR inactive $(100 \mu \mathrm{g}$ protein).

observed for NR activity, NR A. When the cells were grown under anaerobic conditions and in the presence of nitrate, the synthesis of NR was enhanced and, as expected, the NR activity observed on the gel was more intense (Fig. 1a, lane 2). Under these growth conditions, both tellurite (Fig. 1b, lane 2) and selenate (Fig. 1c, lane 2 ) reductase activities were also enhanced. Growth of $E$. coli cells in the absence of nitrate but in the presence of 
(a)

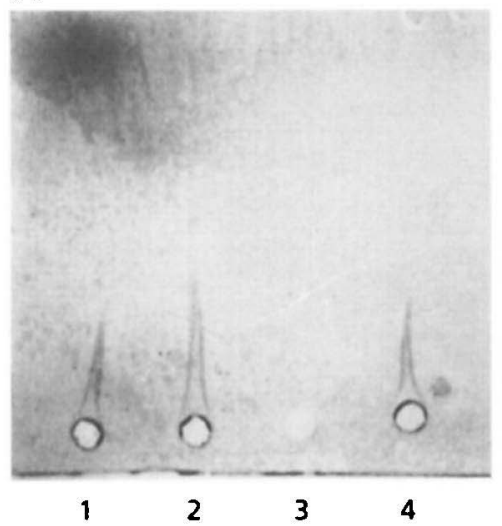

(c)

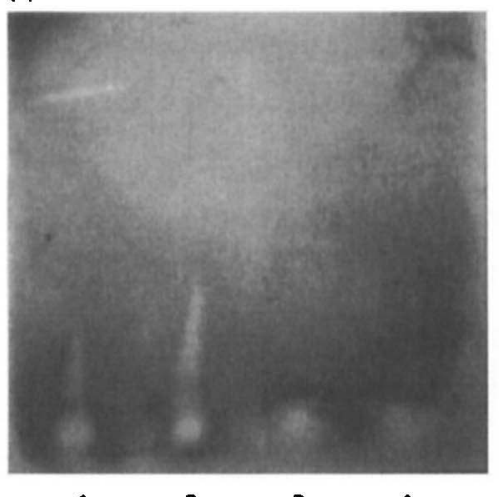

(b)

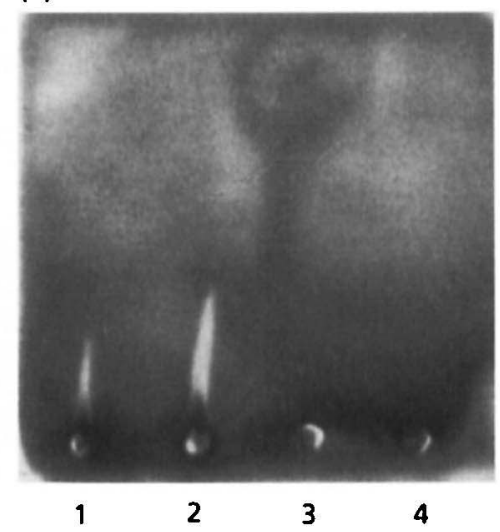

(d)

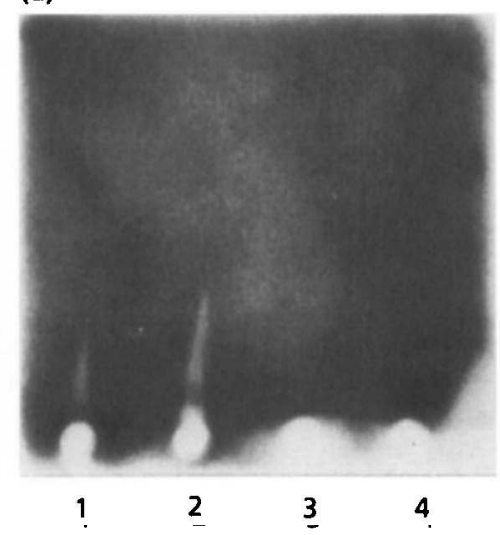

Fig. 3. Identification of the reductase activities by rocket immunoelectrophoresis. The parental strain, MC4100, and mutant were grown anaerobically at $37^{\circ} \mathrm{C}$ on LB medium in presence of $1 \mathrm{~g} \mathrm{KNO}_{3} \mathrm{I}^{-1}$. This analysis was performed as described in Methods using antiserum against NR A. Membrane extracts were loaded in each case. (a) Precipitation arcs revealed by staining with Coomassie brilliant blue; (b) nitrate reductase activity with methyl viologen as electron donor; (c) tellurite reductase activity with methyl viologen as electron donor; (d) selenate reductase activity on rocket immunoelectrophoresis stained with methyl viologen as electron donor. Lanes: 1, parental strain, MC4100 (400 $\mu \mathrm{g}$ proteins); 2 , LCB333/pVA70 (100 $\mu \mathrm{g}$ proteins); 3, LCB2048 (400 $\mu \mathrm{g}$ proteins); 4, TP100 (400 $\mu \mathrm{g}$ proteins). tellurite $(10 \mu \mathrm{M})$ or selenate $(100 \mu \mathrm{M})$ did not induce the appearance of novel bands on non-denaturing gels of either soluble (data not shown) and membrane fractions (Fig. 1). Addition of tellurite $(10 \mu \mathrm{M})$ or selenate $(100 \mu \mathrm{M})$ induced a slight decrease $(20$ to $30 \%)$ in the synthesis of NR (Fig. 1, compare lane 1 to lanes 3 and 4). This effect has been confirmed by measurements of NR concentration by immunoprecipitation and of $\beta$-galactosidase activities with a narG::lacZ transcriptional fusion (unpublished results). These experiments using $\mathrm{MV}^{-}$as the electron donor indicate that NR has both tellurite and selenate reductase activities. The results also indicate that tellurite and selenate do not induce the expression of other reductases which can use $M^{-} \cdot$ to reduce oxyanions.

We analysed the nitrate, tellurite and selenate reductase activities for membrane fractions of different mutants grown anaerobically (Fig. 2). Strain LCB2048 is deleted in NR A and NR Z, while strain TP100 is altered in the synthesis of molybdenum cofactor and synthesizes NR $A$ and $N R Z$ in an inactive form. For both mutants, no decoloration of $\mathrm{MV}^{-}$appeared upon addition of nitrate, tellurite or selenate (Fig. 2, lanes 4 and 5). For strain LCB333/pVA70, overexpressing NR A, the activities of nitrate, tellurite or selenate reductases were very intense, as shown by the strong decoloration band observed on the gel upon addition of the different substrates $\left(\mathrm{KNO}_{3}, \mathrm{~K}_{2} \mathrm{TeO}_{3}\right.$ and $\left.\mathrm{Na}_{2} \mathrm{SeO}_{4}\right)$ (Fig. 2, lane
2). When NR $Z$ is overproduced, using pLCB14, it has been shown that NR $Z$ accumulates to levels which give a clear band with a different $\mathrm{R}_{F}$ value from NR A (Iobbi et al., 1987). When the gel containing LCB333/pLCB14 was exposed to tellurite and selenate, a unique band was observed with the same $\mathrm{R}_{F}$ value as NR Z (Fig. 2, lane 3).

\section{Nitrate reductase is responsible for the tellurite and selenate reductase activities}

Further evidence for the involvement of NRs $A$ and $Z$ in tellurite and selenate reduction was obtained by rocket immunoelectrophoresis. Since the antigenic sites of the NRs are not localized at the catalytic site, NR activity is retained after immunoprecipitation, and it can be detected on the rocket immunoelectrophoresis stained with methyl viologen as the electron donor. Fig. 3 shows that the oxidation of methyl viologen upon addition of nitrate, tellurite or selenate as electron acceptor strictly coincides with precipitation arcs of MC4100 and LCB333/pVA70. For strain LCB2048, devoid of NR A and $Z$, no immunoprecipitated line or reductase activity was detected. For strain TP100, where the NR is present but inactive, the precipitation arc was present, but no nitrate, tellurite or selenate activities could be observed. Similarly, experiments performed using NR Z antiserum showed that this enzyme also has tellurite and selenate reductase activities (data not shown). This series of 


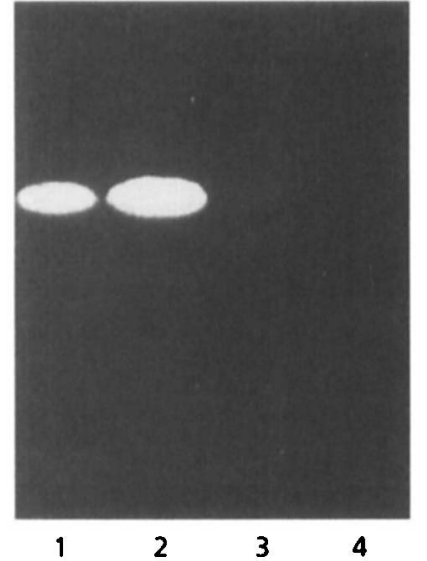

Fig. 4. Identification of a tellurite reductase that is expressed only anaerobically. Soluble extracts from the NR A- and NR Zdeleted mutant strain (LCB2048) were loaded onto a $7.5 \%$ nondenaturing polyacrylamide gel and stained with reduced methyl viologen. Lanes 1 and 2, cells grown under anaerobic conditions without and with potassium nitrate $\left(1 \mathrm{~g} \mathrm{l}^{-1}\right)$, respectively. Lanes 3 and 4, cells grown aerobically without and with potassium nitrate $\left(1 \mathrm{~g} \mathrm{l}^{-1}\right)$, respectively.

experiments clearly shows that, in E. coli, the major enzymes responsible for both tellurite and selenate reduction, mediated by $\mathrm{MV}^{-}$or $\mathrm{BV}{ }^{\top}$, are the membrane NRs A and Z.

In addition to tellurite and selenate we also investigated the other oxyanions of these elements. When selenite or tellurate was added as electron acceptor, no decoloration of $\mathrm{MV}^{-}$was observed in the rockets (data not shown).

\section{Nitrate, selenate and tellurite reduction activities in the soluble fraction from anaerobic cultures}

When grown under anaerobic conditions, the wild-type strain and the NR A overexpressing strain (LCB79/ pVA700) showed a low level of reductase activity in the soluble fraction. This activity was about $5 \%$ of the reductase activities observed in membranes from the same culture. This activity was identified as NR A by its $\mathrm{R}_{F}$ value in non-denaturing polyacrylamide gels and by rocket immunoelectrophoresis (data not shown).

A strain devoid of NR A and NR Z (LCB2048) grown anaerobically revealed the presence of another enzyme with both nitrate and tellurite reductase activity. Using an extended incubation time (greater than $20 \mathrm{~min}$ ), a band of decoloration appeared upon addition of tellurite on a $\mathrm{MV}^{-}$stained non-denaturing polyacrylamide gel, which had an $\mathrm{R}_{F}$ value unique from NR $\mathrm{A}$ and $\mathrm{NR} Z$ (Fig 4).

It is important to note that this newly identified tellurite reductase activity is very difficult to detect even when low levels of NR $A$ and $Z$ are present in the supernatant. This activity is not present under aerobic conditions. We conclude that in E. coli, a soluble enzyme, present in low
Table 3. Tellurite MICs of wild-type and nar mutants

MICs were determined on LB agar media with no additional nitrate added.

\begin{tabular}{|lcc|}
\hline Strain & \multicolumn{2}{c|}{$\mathrm{MIC}\left(\mu \mathrm{g} \mathrm{K}_{2} \mathrm{TeO}_{3} \mathrm{ml}^{-1}\right)$} \\
\cline { 2 - 3 } & Aerobic & Anaerobic \\
\hline MC4100 & 2 & 4 \\
LCB2048 & $0 \cdot 03$ & 4 \\
LCB333/pLCB14 & $0 \cdot 06$ & 4 \\
LCB333 & $0 \cdot 03$ & 4 \\
LCB79/pVA700 & $8-16$ & $8-16$ \\
HB101/pVA700 & 32 & 32 \\
\hline
\end{tabular}

concentration, also has $\mathrm{MV}\ulcorner/$ tellurite oxidoreductase activity.

\section{Minimal inhibitory concentrations}

The MICs of tellurite were determined for different NR mutants of E. coli under both aerobic and anaerobic conditions. The results are summarized in Table 3. MC4100 showed a low-level resistance to $\mathrm{TeO}_{3}^{2-}$, which is typical of wild-type E. coli strains (Summers \& Jacoby, 1977; Jobling \& Ritchie, 1987; Moore \& Kaplan, 1992; Taylor et al., 1994). As previously shown by Turner et al. (1995), the NR deletion mutant (LCB2048) is hypersensitive to $\mathrm{TeO}_{3}^{2-}$ under aerobic conditions. We find that when the NRs are inactive (mutant TP100), the culture is also hypersensitive under aerobic conditions. Overexpression of NR A by LCB79/ pVA700 mediates significant tellurite-resistance levels under both aerobic and anaerobic conditions. Going from aerobic to anaerobic conditions in the wild-type induces a tenfold increase of NR A synthesis. However, we observed only a twofold increase in tellurite resistance. Mutant LCB333 harbouring the NR Z plasmid, pLCB14, did not express tellurite resistance, most likely due to the low level of expression.

Under anaerobic growth conditions, mutants deleted in NR activity do not show increased sensitivity and have the same level of resistance as wild-type. This lack of hypersensitivity may be due to the other tellurite reductase activity, observed at a different $\mathrm{R}_{F}$ to NR A and $\mathrm{Z}$, present in the soluble fraction under anaerobic growth conditions (see above). Additionally, there may be additional enzymes which are not detectable using our $\mathrm{BV}^{-}$and $\mathrm{MV}^{-}$based assays.

The MIC of selenate for all strains tested was greater than $33 \mathrm{mg} \mathrm{ml}^{-1}$, showing that selenate is not toxic for E. coli. The absence of NR does not cause hypersensitivity, contrary to what is observed with tellurite.

\section{Growth on tellurium and selenium oxyanions}

To determine whether the observed reductase activities are bioenergetically linked, wild-type MC4100 was grown anaerobically on minimal medium with 
oxyanions as the sole terminal electron acceptor. No growth was observed for tellurite $\left(1\right.$ and $\left.4 \mu \mathrm{g} \mathrm{ml}^{-1}\right)$, tellurate $\left(2 \mu \mathrm{g} \mathrm{ml}^{-1}\right)$, selenite $\left(100 \mu \mathrm{g} \mathrm{ml}^{-1}, 1\right.$ and $10 \mathrm{mg}$ $\left.\mathrm{ml}^{-1}\right)$ or selenate $\left(100 \mu \mathrm{g} \mathrm{ml}^{-1}, 1\right.$ and $\left.10 \mathrm{mg} \mathrm{m}^{-1}\right)$, whereas growth was observed in control cultures where nitrate $\left(100 \mu \mathrm{g} \mathrm{ml}^{-1}, 1\right.$ and $\left.10 \mathrm{mg} \mathrm{ml}^{-1}\right)$ was provided. Additionally, cultures harbouring plasmids containing the tellurite-resistance determinants $t e h A B$ and klaAklaBtelB could not grow with tellurite $(50$ and $100 \mu \mathrm{g} \mathrm{ml}^{-1}$ ) as the terminal electron acceptor. Nevertheless, mutant LCB79/pVA700, which synthesizes NR $A$ in the presence of IPTG, is able to grow in the presence of tellurium and selenium oxides (the same concentrations as used above) upon addition of $0.2 \mathrm{mM}$ IPTG. These results suggest that $E$. coli can utilize these oxyanions for anaerobic respiration only when NR is induced in large quantities.

\section{DISCUSSION}

Using different biochemical approaches and mutants of $E$. coli, we have shown that NRs A and Z also catalyse tellurite and selenate reduction. In the case of tellurite, we were not able to check whether NR is responsible for the total reduction of $\mathrm{Te}^{\mathrm{IV}}$ into $\mathrm{Te}^{0}$ or whether this reaction is the result of two enzymic steps. The only + II valence intermediate possible in the reduction of tellurite to tellurium is $\mathrm{TeO}$. This oxyanion is very unstable. It has been reported that reduction of $\mathrm{TeO}_{3}^{2-}$ at a mercury electrode undergoes reduction to $\mathrm{Te}^{0}$ in a single step or through a short-lived $\mathrm{Te}^{\mathrm{III}}$ species (Cooper, 1971). Therefore, it is possible that NR could reduce $\mathrm{TeO}_{3}^{2-}$ directly to $\mathrm{Te}^{0}$. However, NR activity is not the only process responsible for the deposition of $\mathrm{Te}^{\mathbf{0}}$ in $E$. coli, since mutants of NR exposed to tellurite still turn black as a result of tellurite reduction. It is clear that other biochemical processes are present under both aerobic and anaerobic conditions which give rise to tellurite reduction. These other reductive processes were not identified by our $\mathrm{BV}^{-}$and $\mathrm{MV}^{-}$- dependent assays. They are likely to involve the thiol redox components of the cell (Turner et al., 1995; unpublished results).

The tellurite reductase activity of NR has an important effect on the resistance of $E$. coli to this oxyanion. Mutants of NR are hypersensitive to tellurite under aerobic conditions (Table 3). This hypersensitivity was absent when the resistance was assessed anaerobically. On rich medium, under aerobic conditions, wild-type E. coli synthesizes a low level of NR A. The data imply that the minor amount of NR expressed aerobically is responsible for the wild-type tellurite-resistance levels, and that the absence of NR has direct consequences. A low threshold level of NR A is required for increased resistance; we observed that overexpression of NR A gives a higher level of tellurite resistance either aerobically or anaerobically in the mutant LCB79/pVA700. These results imply that tellurite reduction via NR is a mechanism used by the bacteria to detoxify this oxyanion. Under anaerobic conditions, the NR mutants are not hypersensitive to tellurite. It is likely that this lack of hypersensitivity to tellurite is due the con- tribution of the additional enzyme we detected in the soluble fraction under anaerobic growth conditions which possesses tellurite reduction activity.

In addition to the reduction of tellurite into tellurium, several other possible mechanisms, such as reduced uptake and increased efflux, sequestration, and the repair of cellular damage can explain the resistance of E. coli to this oxyanion (see Turner et al., 1995, for a detailed discussion). Although the exact biochemical mechanisms have still to be identified for teh $A B$ (Taylor et al., 1994) and klaAklaBtelB (Turner et al., 1994) tellurite-resistance determinants, the resistance level for these determinants was lowered when introduced into the mutant LCB2048 (deleted in NR A and NR Z) and their MIC decreased by a factor of 8-16 (Turner et al., 1995). These results also imply the important function of NR in the tellurite resistance.

Thauera selenatis has been reported to use selenate as an electron acceptor for anaerobic respiration (Macy, 1994). This bacterium possesses a specific selenate reductase different from NR as well as a single nitrite reductase able to reduce both nitrite and selenite. The ability of E. coli to reduce tellurite and selenate opens the possibility that these compounds serve as electron acceptors for anaerobic respiration. However, growth of $E$. coli with tellurium and selenium oxyanions as electron acceptors was only obtained under anaerobic conditions in a mutant where NR is induced by IPTG. Therefore, the reduction of tellurite or selenate by E. coli (wild-type) does not play an important role in the bioenergetic process of this organism, but appears to provide a defence against oxyanions for the cell.

The ability of the membrane-bound NRs of E. coli to reduce chlorate or bromate is a well-known phenomenon (Iobbi et al., 1987; Morpeth \& Boxer, 1985). We have shown here that these enzymes possess tellurite and selenate reductase activity. This is apparently a common feature of different types of NRs. Indeed, we have observed that the membrane NR of Alcaligenes eutrophus, Paracoccus denitrificans and the soluble periplasmic NR of Rhodobacter sphaeroides subsp. denitrificans present high tellurite and selenate reductase activities (Avazéri et al., 1995; unpublished results).

Our observation that different types of NR are able to reduce selenate explains the field observation of Oremland (1994). This author reported that nitrate and selenate reductions in situ give a similar profile as a function of the depth of the sediment. Different sets of experiments done on irrigation drainage water of the San Joaquin Valley (California) have shown that selenate reduction is inhibited by the presence of oxygen or nitrate (Lundquist et al., 1994). These observations are consistent with our proposal that NR has an important role in selenate reduction. Indeed the synthesis of this enzyme is inhibited by aerobiosis, and nitrate is a much better substrate than selenate ( $T$. Montarges, unpublished results). 
In this study we found that the membrane-bound NRs A and $\mathrm{Z}$ of E. coli possess tellurite and selenate reductase activities. We also identified tellurite reductase activity that is expressed only under anaerobic conditions. The reduction activities are not used as bioenergetic processes but help the bacteria through detoxification of the oxyanions.

\section{ACKNOWLEDGEMENTS}

The research of C.A. has been made possible by the financial support of the Agence de l'Environnement et de la Maitrise d'Energie and the Commissariat à l'Energie Atomique. C.A. wishes to thank Dr Francis Blasco for providing plasmids and all the Laboratoire de Chimie Bactérienne for their help and discussions.

J.H.W. wishes to thank the Medical Research Council of Canada for the funding which was contributed, by a joint NATO collaborative grant, to G. G. and J.H.W. Travel funds for G.G. were provided by the Alberta Heritage Foundation for Medical Research. R.J.T. wishes to thank Dr Diane E. Taylor for useful discussions and support.

\section{REFERENCES}

Avazéri, C., Pommier, J., Blasco, F., Giordano, G. \& Verméglio, A. (1995). Reduction of oxyanions by photosynthetic bacteria and E. coli: role of the nitrate reductase in the reduction of tellurite and selenate. In Photosynthesis: From Light to Biosphere, pp. 423-426. Edited by P. Mathis. Dordrecht: Kluwer.

Barrnett, R. J. \& Palade, G. E. (1957). Histochemical demonstration of the sites of activity of dehydrogenase systems with the electron microscope. J Biophys Biochem Cytol 3, 577-587.

Blasco, F., lobbi, C., Giordano, G., Chippaux, M. \& Bonnefoy, v. (1989). Nitrate reductase of the Escherichia coli: completion of the nucleotide sequence of the nar operon and reassessment of the role of the $\alpha$ and $\beta$ subunits in iron binding and electron transfer. Mol Gen Genet 218, 249-256.

Blasco, F., lobbi, C., Ratouchniack, J., Bonnefoy, V. \& Chippaux, M. (1990). Nitrate reductase of Escherichia coli: sequence of the second nitrate reductase and comparison with the encoded by the narGHJI operon. Mol Gen Genet 222, 104-111.

Blasco, F., Nunzi, F., Pommier, J., Brasseur, R., Chippaux, M. \& Giordano, G. (1992). Formation of active heterologous nitrate reductases between nitrate reductases $A$ and $Z$ of Escherichia coli. Mol Microbiol 6, 209-219.

Bonnefoy, V., Burini, J. F., Giordano, G., Pascal, M. C. \& Chippaux, M. (1987). Presence in the silent terminus region of the Escherichia coli $\mathrm{K}-12$ chromosome of cryptic gene(s) encoding a new nitrate reductase. Mol Microbiol 1, 143-150.

Boyer, H. W. \& Roulland-Dussoix, D. (1969). A complementation analysis of the restriction and modification of DNA in Escherichia coli. J Mol Biol 41, 459-472.

Casadaban, M. J. (1976). Transposition and fusion of the lac genes to selected promoters in Escherichia coli using bacteriophage lambda and mu. $J$ Mol Biol 104, 541-555.

Chippaux, M., Bonnefoy, V., Ratouchniack, J. \& Pascal, M. C. (1981). Operon fusions in the nitrate reductase operon and study of the control gene nirR in Escherichia coli. Mol Gen Genet 182, $477-479$.

Cooper, W. C. (editor) (1971). In Tellurium. Edited by W. C. Cooper. New York: Van Nostrand Reinhold.
Gerrard, T. L., Telford, J. N. \& Williams, H. H. (1974). Detection of selenium deposits in Escherichia coli by electron microscopy. $J$ Bacteriol 119, 1057-1060.

Graham, A., Jenkins, H. E., Smith, N. H., Mandrand, M. A., Haddock, B. A. \& Boxer, D. H. (1980). The synthesis of formate dehydrogenase and nitrate reductase proteins in various $f d b$ and chl mutants of Escherichia coli. FEMS Microbiol Lett 7, 145-151.

Guigliarelli, B., Asso, M., More, C., Augier, V., Blasco, F., Pommier, J., Giordano, G. \& Bertrand, P. (1992). EPR and redox characterization of iron-sulfur centers in nitrate reductases $\mathrm{A}$ and $\mathrm{Z}$ from Escherichia coli. Eur J Biochem 207, 61-68.

Guigliarelli, B., Magalon, A., Asso, M., Bertrand, P., Frixon, C., Giordano, G. \& Blasco, F. (1996). Complete coordination of four $\mathrm{Fe}-\mathrm{S}$ centers of the $\beta$ subunit from Escherichia coli nitrate reductase. Physiological, biochemical, and EPR characterization site-directed mutants lacking the highest or lowest potential (4Fe-4S) cluster. Biochemistry 35, 4828-4836.

Hill, S. M., Jobling, M. G., Lloyd, B. H., Strike, P. \& Ritchie, D. A. (1993). Functional expression of the tellurite resistance determinant from the IncHI2 plasmid pMER610. Mol Gen Genet 241, 203-212.

lobbi, C., Santini, C. L., Bonnefoy, V. \& Giordano, G. (1987). Biochemical and immunological evidence for a second nitrate reductase in Escherichia coli K-12. Eur J Biochem 168, 451-459.

lobbi-Nivol, C., Santini, C. L., Blasco, F. \& Giordano, G. (1990). Purification and further characterization of the second nitrate reductase of Escherichia coli K-12. Eur J Biochem 188, 679-687.

Jobling, M. G. \& Ritchie, D. A. (1987). Genetic and physical analysis of plasmid genes expressing inducible resistance to tellurite in Escherichia coli. Mol Gen Genet 208, 288-293.

Jones, R. W. \& Garland, P. B. (1977). Sites and specificity of the reaction of bipyridylium compounds with anaerobic respiratory enzymes of Escherichia coli. Biochem J 164, 199-211.

Kapraleck, A., Jechova, E. \& Otavova, M. (1982). Two sites of oxygen control in induced synthesis of respiratory nitrate reductase in Escherichia coli. J Bacteriol 149, 1142-1145.

Lloyd Jones, G., Osborn, A. M., Ritchie, D. A., Strike, P., Hobman, J. L., Brown, N. L. \& Rouch, D. A. (1994). Accumulation and intracellular fate of tellurite resistant in Escherichia coli: a model for the mechanism of resistance. FEMS Microbiol Lett 118, 113-120.

Lund, K. \& DeMoss, J. A. (1976). Association-dissociation behavior and subunits structure of heat-released nitrate reductase from Escherichia coli. J Biol Chem 251, 2207-2213.

Lundquist, T. J., Bailey Green, F., Blake Tresan, R., Newman, R. D. \& Oswald, W. J. (1994). The algal-bacterial selenium removal system: mechanisms and field study. In Selenium in the Environment, pp. 251-278. Edited by J. R. Frankenberger \& S. Benson. New York: Marcel Dekker.

Macy, J. M. (1994). Biochemistry of selenium metabolism by Thauera selenatis gen. nov. sp. nov. and use of the organism for remediation of selenium oxyanions in San Joaquim Valley drainage water. In Selenium in the Environment, pp. 421-444. Edited by J. R. Frankenberger \& S. Benson. New York: Marcel Dekker.

Miller, J. H. (1992). A Short Course in Bacterial Genetics. Cold Spring Harbor, NY: Cold Spring Harbor Laboratory.

Moore, M. D. \& Kaplan, S. (1992). Identification of intrinsic high level resistance to rare earth oxides and oxyanions in members of the class Proteobacteria : characterization of tellurite, selenite and rhodium sesquioxide reduction in Rhodobacter sphaeroides. J Bacteriol 174, 1505-1514. 
Morpeth, F. \& Boxer, D. (1985). Kinetic analysis of respiratory nitrate reductase from Escherichia coli K12. Biochemistry 24, $40-46$.

Oremland, R. S. (1994). Biogeochemical transformations of selenium in anoxic environments. In Selenium in the Environment, pp. 389-420. Edited by J. R. Frankenberger \& S. Benson. New York: Marcel Dekker.

Palmer, T., Santini, C. L., lobbi-Nivol, C., Eaves, D., Boxer, D. \& Giordano, G. (1996). Involvement of the narJ and mob gene products in distinct steps in the biosynthesis of the molybdoenzyme nitrate reductase in Escherichia coli. Mol Microbiol 20, 875-884.

Pascal, M. C., Burini, J. F., Ratouchniak, J. \& Chippaux, M. (1982). Regulation of the nitrate reductase operon: effects of mutations in chlA, B, D and E genes. Mol Gen Genet 188, 103-106.

Sodergren, E. J. \& De Moss, J. A. (1988). narl region of the Escherichia coli nitrate reductase (nar) operon contains two genes. J Bacteriol 170, 1721-1729.

Summers, A. O. \& Jacoby, G. A. (1977). Plasmid-determined resistance to tellurium compounds. J Bacteriol 129, 276-281.

Summers, A. O. \& Silver, S. (1978). Microbial transformation of metals. Annu Rev Microbiol 32, 637-672.

Stewart, V. (1982). Requirement of Fnr and NarL functions for nitrate reductase expression in Escherichia coli K-12. J Mol Biol 151, 1320-1325.

Taylor, D. E., Walter, R., Sherburne, R. \& Bazette-Jones, P. (1988). Structure and location of tellurium deposits in Escherichia coli cells harboring tellurite resistance plasmid. J Ultrastruct $\mathrm{Mol}$ Struct Res 99, 18-26.

Taylor, D. E., Hou, Y., Turner, R. J. \& Weiner, J. H. (1994). Location of a potassium tellurite resistance operon (tehAtehB) within the terminus of Escherichia coli K-12. J Bacteriol 176, 2740-2742.
Turkey, F. L., Walper, J. F., Appleman, M. D. \& Donohue, J. (1962). Complete reduction of tellurite to pure tellurium metal by microorganisms. J Bacteriol 83, 1313-1314.

Turner, R. J., Hou, Y., Weiner, J. H. \& Taylor, D. E. (1992). The arsenical ATPase efflux pump mediates tellurite resistance. J Bacteriol 174, 3092-3094.

Turner, R. J., Weiner, J. H. \& Taylor, D. E. (1994). In vivo complementation and site-specific mutagenesis of the tellurite resistance determinant kilAtelAB from IncP $\alpha$ plasmid $\mathrm{RK}_{2} \mathrm{Te}^{\mathrm{r}}$. Microbiology 140, 1319-1326.

Turner, R. J., Weiner, J. H. \& Taylor, D. E. (1995). The telluriteresistance determinants tehAtehB and klaAklaBtelB have different biochemical requirements. Microbiology 141, 3133-3140.

Van Iterson, W. \& Leene, W. (1964). A cytochemical localization of reductive sites in a Gram-negative bacterium. J Cell Biol 20, 377-387.

Vincent, S. P. \& Bray, R. C. (1978). Electron paramagnetic resonance studies on the nitrate reductase from Escherichia coli K-12. Biochem J 171, 639-647.

Walter, E. G. \& Taylor, D. E. (1992). Plasmid mediated resistance to tellurite: expressed and cryptic. Plasmid 27, 52-64.

Walter, E. G., Thomas, C. M., Ibbotson, J. P. \& Taylor, D. E. (1991). Transcriptional analysis, translational analysis and sequence of the kilA tellurite resistance region of plasmid RK2TeR.J Bacteriol 173, 1111-1119.

Zehr, J. P. \& Oremland, R. S. (1987). Reduction of selenate to selenite by sulfate-respiring bacteria: experiments with cell suspensions and estuarine sediments. Appl Environ Microbiol 53, $1365-1369$.

Received 7 August 1996; revised 11 November 1996; accepted 15 November 1996. 